\title{
A HOUSE-TO-HOUSE SURVEY OF EPILEPTIC SEIZURES IN AN URBAN COMMUNITY OF RIO DE JANEIRO, BRAZIL
}

\author{
Marleide da Mota Gomes', Regina Golnner Zeitoune', \\ Leandro Albuquerque Lemgruber Kropf ${ }^{3}$, Erica da Silva van Beeck ${ }^{3}$
}

\begin{abstract}
Objective: To carry out a prevalence study about epileptic seizures and epilepsy in an urban lowincome population. Method: Prevalence study in a two-phase model: screening and diagnosis confirmation. It was applied a structured questionnaire in 982 people all effectively resident on March 1rst 2000 based on a population census previously carried out by the Nurse Faculty. One neurologist interviewed all the suspected cases. Results: It was detected 176 suspected cases of epileptic seizures: 156 with non-epileptic events, and 20 with epileptic seizures. The lifetime point prevalence was of 16.3 cases per 1000 inhabitants, and of active epilepsy, 5.1/ 1000. If we consider false negative diagnosis from the screening procedures, the lifetime pointprevalence rates until 20.8/1000. Conclusion: The prevalence data of epilepsy shows less impressive than in other Latin-American studies and even some Brazilian, but similar to other Brazilian studies. This suggests geographical diversity and/or methodological differences among studies. Anyway, probably the epilepsy prevalence in Rio de Janeiro is not so high as that found in the Latin countries rural areas.
\end{abstract}

KEY WORDS: epilepsy, prevalence, community study.

Estudo porta-a-porta sobre crises epilépticas em comunidade urbana do Rio de Janeiro, Brasil

\begin{abstract}
RESUMO - Objetivo: Estudar a prevalência de crises epilépticas e epilepsia em uma população urbana de baixa renda do Rio de Janeiro. Método: Estudo de prevalência, em um modelo de duas etapas: de triagem e de confirmação diagnóstica. Foi aplicado questionário estruturado de triagem em 982 pessoas. Todos os efetivamente residentes na comunidade em primeiro de março de 2000 (dia prevalente) eram os sujeitos em potencial. A população de estudo foi aquela que constava no censo efetuado pela Escola de Enfermagen Anna Nery. Um neurologista entrevistou os sujeitos suspeitos de apresentarem crises epilépticas. Resultados: Foram detectados 176 casos suspeitos de crises epilépticas: 156 casos com eventos não epilépticos e 20 com crises epilépticas. A prevalência acumulada na comunidade foi 16,3 casos por 1000 habitantes e a de epilepsia ativa foi 5,1 / 1000. Caso se considere o diagnóstico falso negativo da fase de triagem, a prevalência acumulada iria a 20,8/1000. Conclusão: Os dados de prevalência mostram-se menores do que de outros países latinoamericanos e mesmo de alguns brasileiros, mas similares a outros nacionais, o que sugere diversidade geográfica e/ou diferenças metodológicas entre os estudos. A prevalência de epilepsia no Rio de Janeiro provavelmente não é tão alta quanto a de outros países latinos, principalmente nas suas regiões rurais.
\end{abstract}

PALAVRAS-CHAVE: epilepsia, prevalência, estudo de campo.

The epileptic seizures case finding commonly depends on retrospective reviews of medical notes or community surveys ${ }^{1-3}$. The clinical data of a defined population usually recorded in clinical centers can be used for epidemiological purpose, what can be more easily done in developed countries. Although, there is pitfalls in this approach because one has to rely on previous case identification and diagnosis. Surveys based on the Mayo Clinic or the General Practitioners of the United Kingdom records, for instance, use this kind of data with satisfactory approximation to the reality. Unfortunately, in developing countries

\footnotetext{
Programa de Epilepsia do Instituto de Neurologia Deolindo Couto (INDC) e Programa de Epidemiologia Clínica, da Faculdade de Medicina (FM) / Hospital Universitário, Departamento de Saúde Pública da Escola Anna Nery, Universidade Federal do Rio de Janeiro (UFRJ), Rio de Jeniro RJ, Brasil: ${ }^{1}$ Professora Adjunta da FM-UFRJ, Coordenadora do Programa de Epilepsia do INDC; 2 professora Adjunta da Escola Ana Nery-UFRJ, Chefe do Departamento de Saúde Coletiva; ${ }^{3}$ Aluno de Graduação da FM-UFRJ, estudante de iniciação cientítica. Support: This study was partially supported by Conselho Nacional de Pesquisa-CNPq.
}

Received 1 February 2002. Accepted 23 April 2002.

Dra. Marleide da Mota Gomes - Caixa Postal 68008 - Centro de Ciências da Saúde, Bloco K - Cidade Universitária - Ilha do Fundão Avenida Brigadeiro Trompowski s/no - 21941-590 Rio de Janeiro RJ - Brasil. E-mail:mmgomes@hucff.ufrj.br 
this procedure is not feasible because of the lack of representativeness and accuracy of the case registers or medical records of a defined population. Anywhere, the field studies offer the best approach to know the epidemiology of a disease in a defined population. These studies were already carried out in several LatinAmerican countries besides others such as China, USA and Italy ${ }^{1,2,4-6}$. Colombia, Ecuador, Bolivia, Mexico, Guatemala and Chile were the South-Americans countries with these studies, besides Brazil ${ }^{1-3,7-11}$.

There are few published studies about these matter in Brazil ${ }^{12-14}$, consequently, the awareness of the frequency and distribution of epilepsy is limited. The prevalence of epilepsy in Latin-American countries is considered high as a whole ${ }^{1-3}$ but in Brazil, the results (crude prevalence or supposed to be) are very heterogeneous: $13.3 / 1000$ by Marino Jr, et al. ${ }^{12}, 36.8 / 1000$ by Fernandes, et al. ${ }^{13}, 1 / 1.000$ by Almeida Filho, apud Fernandes \& Sander ${ }^{2} ; 7 / 1000$, by Melo-Souza et al. ${ }^{14}$. Indeed, because of the magnitude of the Brazilian population and social-economical-cultural diversity, the reality may differ among the different regions, and even within the same province, mainly regarding urban and rural communities.

Regarding these data heterogeneity and lack of this kind of data in Rio de Janeiro, we proposed to study a low-income urban population in a prevalence study.

\section{METHOD}

The population consisted approximately of 1,300 inhabitants (Fig 1). The study population is based on a population census previously carried out by the Nurse Faculty. The main surveyed area is in University City of the Federal University of Rio de Janeiro. The community area was divided according the streets; each of them served by a group of interviewer. Leader community supported the project.
Study design and quality control - The procedure of the study was based on a two-stepped design. The screening field study - first phase: specially instructed visitors screened the residents. They followed a standard protocol in collecting census data, administering a screening questionnaire. The subjects effectively resident in the community on March first 2000 (prevalence day) were investigated ( $n=$ 982). All those found positive were then interviewed including the interview with a relative or witnesses of the seizures - the second phase. The cases were definitively classified for epilepsy after review of the case record forms if possible.

Screening instrument - We adopted the screening questions of the instrument used in the Ecuadorian study of epilepsy prevalence carried out by Placencia et al. ${ }^{7-9}$. The questionnaire had been translated into Portuguese and pretested in 30 patients on clinical grounds (15 with epilepsy, and the other 15, without). It was included other questions related to demographic and social characteristics. The performance of this pretest was sensibility $93 \%(\mathrm{Cl}, 68.0 \%-99.8 \%)$, and specificity $73 \%(\mathrm{Cl}, 44.9 \%-92.2 \%)$.

The instrument consists of two sections: eligibility and demographic information; symptom and self reported diagnosis of epilepsy questionnaire with precoded answers. The questions were designed to identify all cases that suffered epileptic seizures of any type, single or acute symptomatic. Adults, people with 13 years of age or more, were asked directly (or fulfill the questionnaire oriented by a member of the household - instructed by the interviewer). The child responsible served as the surrogate and answered the questions.

Neurologist examination - A neurologist interviewed the subjects with a positive questionnaire. The screening test was considered positive if the questions 1 and 2 were positive, or any from 3 to 9 . The subjects found to be positive were personally interviewed by the neurologist at home or by phone. In the case of children, it was made by means of the responsible. In case of doubt, it was asked the opinion of a witness of the studied event(s).

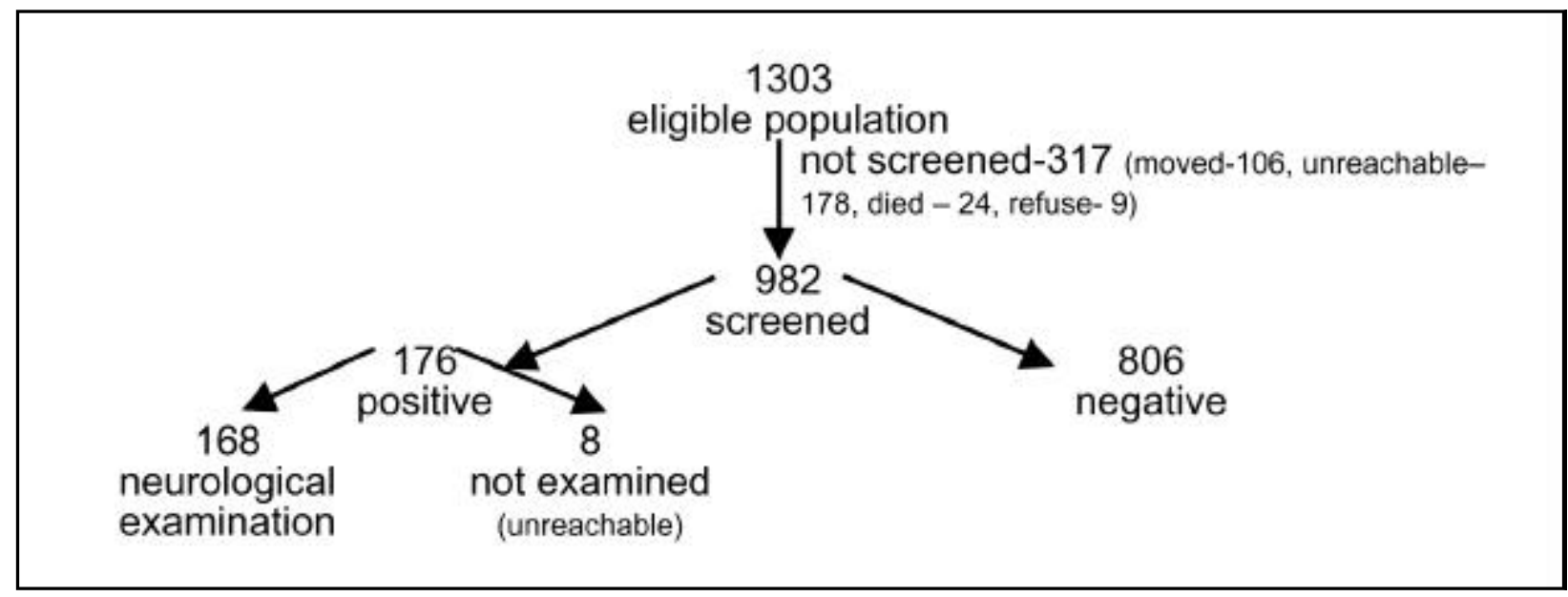

Fig 1. Flow chart of the study population. 
Table 1. Age and sex distribution of the study population ( $N=982)$.

\begin{tabular}{|c|c|c|c|c|c|c|}
\hline \multirow{3}{*}{$\frac{\text { Means }(\mathrm{SD})^{*}}{\text { Age Years }}$} & \multicolumn{2}{|c|}{ Men } & \multicolumn{2}{|c|}{ Women } & \multicolumn{2}{|c|}{ Total } \\
\hline & \multicolumn{2}{|c|}{28.19 (19.6) } & \multicolumn{2}{|c|}{$30.7(20.15)$} & \multicolumn{2}{|c|}{29.5 (19.9) } \\
\hline & $\mathrm{n}$ & $\%$ & $\mathrm{n}$ & $\%$ & $\mathrm{n}$ & $\%$ \\
\hline $0-10$ & 88 & 19,6 & 91 & 17,0 & 179 & 18,84 \\
\hline $11-20$ & 112 & 25,0 & 109 & 20,4 & 221 & 22,5 \\
\hline $21-30$ & 56 & 12,5 & 82 & 15,4 & 138 & 14,0 \\
\hline $31-40$ & 70 & 15,6 & 81 & 15,2 & 151 & 15,3 \\
\hline $41-50$ & 49 & 10,9 & 69 & 12,9 & 118 & 12,0 \\
\hline $51-60$ & 35 & 7,8 & 43 & 8,1 & 78 & 7,9 \\
\hline $61-70$ & 27 & 6,0 & 43 & 8,1 & 70 & 7,1 \\
\hline $71-90$ & 11 & 2,4 & 16 & 3,0 & 27 & 2,7 \\
\hline Total & 448 & 100 & 534 & 100 & 982 & 100 \\
\hline
\end{tabular}

The consultation not included any instrumental test. The neurologist used standardized diagnostic criteria for epilepsy based on Guidelines for Epidemiological Studies on Epilepsy of the ILAE ${ }^{15}$. Epileptic seizures are considered a clinical manifestation presumed to result from an abnormal and excessive discharge of a set of neurons in the brain. Epilepsy is considered a condition characterized by recurrent ( 2 or more $>24 \mathrm{~h}$ ) epileptic seizures, unprovoked by immediate cause. Active epilepsy is a prevalent case of active epilepsy defined as a person with epilepsy who has had at least one epileptic seizure in the previous 5 years, regardless of antiepileptic drug treatment. Febrile seizures is considered an epileptic seizure occurring in childhood after 1 month of age, associated with febrile illness, not caused by an infection of the central nervous system, without previous neonatal seizures, or a previous unprovoked seizure, and not meeting criteria for other acute symptomatic seizures. Non-epileptic events are considered manifestations presumed to be unrelated to an abnormal and excessive discharge of a set of neurons of the brain. The seizure classification was based on the ILAE Classification of type of seizures ${ }^{16}$.

Staff - The study team consisted of 1 neurologist (and also general coordinator), 1 nurse, 40 undergraduate students of Nurse, and 2 of Medicine. The nurse was field supervisor in charge of selection of the studied population and the application of the screening test. The neurologist examined the suspected cases. The medical students with scholarship of the CNPq were in charge of the data base bank entry, and they were also involved in the screening phase, and as neurologist collaborators in the 2nd phase / clinical evaluation.

Timing - The screening door to door phase was performed mainly from March 2000 to early 2001.
Analysis - Descriptive analysis of data regarding age, sex, occupation ARE items of the screening questionnaire. It was calculated the crude prevalence (active and nonactive epilepsy) and prevalence of active epilepsy taking or not in account the probable false negative data based on the same kind of data of the Placencia et al., 1992 study $^{8}$ (missing rate of $0,44 \%$ ). The statistical package Epi Info 6.01 was used for the analysis.

\section{RESULTS}

982 people were interviewed. The population characteristics are presented in the Table 1. The cases were mainly divided among generalized or partial types (Table 2). The lifetime point-prevalence rates between 16.2/1000 and 20.2/1000 (minimum rate calculated based on the study data, and maximum estimated rates, calculated by the probability of false negatives). The active epilepsy prevalence rate was 5.1 / 1000 (Table 3). All the diagnosed patients with active or inactive epilepsy were regularly taking antiepileptic drugs at the present or at the past, in the inactivated cases.

Table 2. Types of seizures predominant in each patient.

\begin{tabular}{lc}
\hline Type of seizure & N (\%) \\
\hline Generalized tonic-clonic & $8(40.0)$ \\
Absence or partial complex & $2(10.0)$ \\
Partial & $7(35.0)$ \\
Not classifed & $3(15.0)$ \\
Total & $20(100)$ \\
\hline
\end{tabular}


Table 3. Summary of epidemiological findings.

\begin{tabular}{lccccc}
\hline Epilepsy & Male & Female & Total & $\begin{array}{c}\text { Age } \\
\text { Means(sd) }\end{array}$ & $\begin{array}{c}\text { Prevalence } \\
/ 1000\end{array}$ \\
\hline Active cases & 3 & 2 & 5 & $36.1(30.0)$ & 5.1 \\
Inactive & 5 & 6 & 11 & $27.9(13.9)$ & 11.2 \\
$\begin{array}{l}\text { Single epileptic seizures } \\
\text { (without identifiable cause) }\end{array}$ & 2 & 2 & 4 & $30.1(14.4)$ & 4.1 \\
Lifetime prevalence & 8 & 8 & 16 & - & \\
Total & 10 & 10 & 20 & $24.4(21.4)$ & 20.4 \\
\hline
\end{tabular}

\section{DISCUSSION}

There are several problems to be faced on epidemiological study of epilepsy, mainly one of diagnosis. This study faced this problem, at least partially, because of the homogeneously applied diagnostic criteria - only one neurologist with experience with epilepsy examined the suspected cases. The cases with more subtle forms could be underestimated reducing the sensitivity of the screening questionnaire. Considering this pitfall we made an approximate calculation of these potential loss taking in account the performance of false negative rates of the Placencia et al., 1992 study $^{8}$. It was not rejected the possibility of the population to under report manifestations suspected of being part of the epilepsy. The present study revealed lower rates than that of Fernandes et al., $1992^{13}$ both for crude prevalence and active epilepsy; similar to the Marino et al, 1982 study $^{12}$; and higher relating to the Melo-Souza et al. ${ }^{14}$. The reasons for theses difference can be related to real differences among the regions (incidence of cysticercosis, probably lower in Rio de Janeiro) as well as methodological differences of the studies, and even our small studied population. Consequently, it is a possibility that the supposed high prevalence of epilepsy in Brazil as a whole is not true as initially supposed. Anyway, we have to consider each region in particular, regarding this nosological distribution and also the study of a larger population. Another issue is related to the medication, all the patients were taking antiepileptic drugs when it was due, probably linked to the good health coverage.

\section{REFERENCES}

1. Sander JWAS, Shorvon SD. Epidemiology of the epilepsies. J Neurol Neurosurg Psychiatry 1996;61:433-443.

2. Fernandes JG, Sander JWAS. Epidemiologia e história natural das epilepsias. In Costa JC, Palmini A, Yacubian EMT, Cavalheiro EA. Fundamentos neurobiológicos das epilepsias: aspectos clínicos e cirúrgicos (eds). São Paulo: Lemos Editorial, 1998:3-20.

3. Gomes MM. Epidemiologia: distribuição, fatores de risco e considerações epidemiológicas. In Guerreiro CAM, Guerreiro MM, Cendes F, LopesCendes I (eds). Epilepsia. São Paulo: Lemos Editorial, 2000:11-21.

4. Li SC, Schoenberg BS, Wang CC, Cheng XM, Zhou SS, Bolis CL. Epidemiology of epilepsy in urban areas of the People's Republic of China. Epilepsia 1985;26:391-394.

5. Haerer AF, Anderson DW, Schoenberg BS. Prevalence and clinical features of epilepsy in a biracial United States population. Epilepsia 1982;27:66-75.

6. Morgante L, Grigoletto F, Meneghini F, et al. Neuroepidemiological survey on Sicilian population: a feasibility study. Neuroepidemiology 1989;8:214-220

7. Placencia M, Sander JWAS, Shorvon SD, Ellison RH, Cascante SM. Validation of a screening questionnaire for the detection of epileptic seizures in epidemiological studies. Brain 1992;115:783-794.

8. Placencia M, Shorvon SD, Paredes V, et al. Epileptic seizures in na Andean region of Ecuador: incidence and prevalence and regional variation. Brain 1992;115:771-782.

9. Placencia M, Suarez J, Crespo F, et al. A large scale study of epilepsy in Ecuador: methodological aspects. Neuroepidemiology 1992;11:74-84.

10. Salazar E, Paradisi F, Tempera G, Hall A. A neuroepidemiological survey in rural Bolivia: background and methods. Neuroepidemiology 1998;17:273-280.

11. Garcia-Noval J, Moreno E, Mata F, Alfaro HS. An epidemiological study of epilepsy and epileptic seizures in two rural Guatemalan communities. Ann Trop Med Paras 2001;95:167-175.

12. Marino R Jr, Cukiert A, Pinho A, Pinho E. Aspectos epidemiológicos da epilepsia em São Paulo. Arq Neuropsiquiat 1982;44:243-254.

13. Fernandes JG, Schmidt MI, Tozzi S, Sander JWAS. Prevalence of epilepsy: the Porto Alegre study. Epilepsia 1992;33(Suppl 3):132.

14. Melo-Souza SE, Tolentino MAS, Parada JCB, Oliveira ELG, Alves MAC Epidemiologia da epilepsia em Goiânia-Brasil. Arq Neuropsiqiat 2000; 58(Suppl 2):30.

15. Comission on Epidemiology and Prognosis, International League Against Epilepsy. Guidelines for epidemiological studies on epilepsy. Epilepsia 1993;34:592-596.

16. Comission on Classification and Terminology of the International League Against Epilepsy. Proposal for revised clinical and electroencephalographic classification of epileptic seizures. Epilepsia 1981; 22:489-501. 